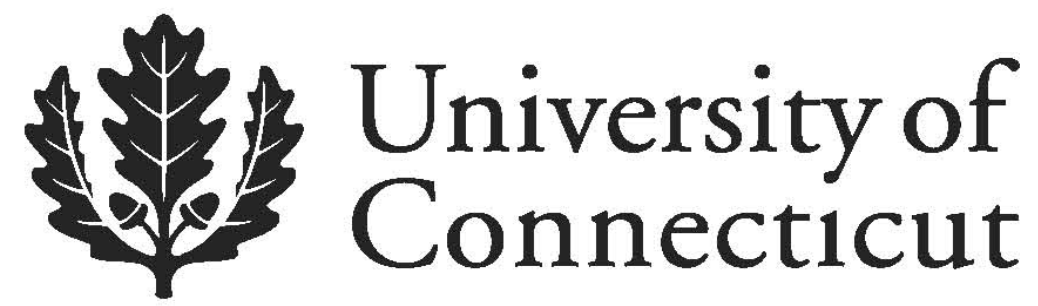

Department of Economics Working Paper Series

The Political Economy of Law and Economic Development in Islamic History

Metin M. Coşgel

University of Connecticut

Working Paper 2012-44

December 2012

365 Fairfield Way, Unit 1063

Storrs, CT 06269-1063

Phone: (860) 486-3022

Fax: (860) 486-4463

http://www.econ.uconn.edu/

This working paper is indexed on RePEc, http://repec.org 


\title{
The Political Economy of Law and Economic Development in
}

\section{Islamic History}

\author{
Metin M. Coşgel* \\ University of Connecticut
}

December, 2012

\begin{abstract}
There appear to be two seemingly contradictory images of law and economic change in the Islamic world. Whereas some scholars have viewed Islamic societies as rigid and incapable of adapting to a changing environment, others have held the opposite image of Islamic societies as flexible, quick to adapt to change, and conducive to economic development. Researchers have often focused on either stagnation or change as being the more representative image that needs explanation, rarely looking to explain why both images coexisted. Using a political economy approach, this paper explains the nuanced flexibility of Islamic law by focusing on the relationship between the ruler and the legal-religious community. This community has been an influential group in Islamic societies because of its power in the interpretation and adjudication of the law and its ability to confer legitimacy on the rulers. Change or stagnation has emerged as the outcome of the strategic interaction between the rulers and legal community, rather than from a fixed characteristic of Islamic societies or an intrinsic quality of a new development.
\end{abstract}

Journal of Economic Literature Classification: D7, H2, H3, N7, O3, O5, P48, P5, Z12

Keywords: Islamic law, change, stagnation, technology, legal community, political economy

*Professor of Economics, University of Connecticut, Storrs, CT 06269-1063, Ph: (860) 486-4662, Fax: (860) 486-4463, e-mail: metin.cosgel@uconn.edu. I wish to acknowledge useful comments and suggestions received from Debin Ma, Tom Miceli, Jared Rubin, Jan Luiten van Zanden, and participants at the Law and Economic Development conference in Utrecht, The Netherlands, in September 2007. 


\section{Introduction}

There appear to be two seemingly contradictory images of law and economic change in the Islamic world. There is, on the one hand, the image of Islamic societies as being rigid and incapable of adapting to a changing environment, legal rigidities creating major obstacles to economic development. The Ottomans banned mass printing in Ottoman Turkish (in Arabic characters) until the eighteenth century, almost three centuries after the invention of moveable type. The Ottoman Engineering School similarly did not introduce modern developments in physics, chemistry, and other natural sciences into its curriculum until the nineteenth century, and the legal system did not recognize some fundamental organizational developments such as the concept of a corporation. These examples support the image of an extremely conservative Islamic world, missing out or receiving with significant delay the benefits of various scientific, technological, and institutional developments that other parts of the world realized in long-term economic growth and higher standards of living.

The opposite image of Islamic societies as flexible, quick to adapt to change, and conducive to economic development also exists. While some schools did not teach modern natural sciences, others did. Though slow to adopt the printing press in the fifteenth century, Muslims had previously been very quick to adopt paper, a Chinese invention of comparable magnitude to the printing press in the history of communications technology. They similarly appropriated the bulk of Greek science and philosophy during the eighth and ninth centuries, and they were at the forefront of scholarly, scientific, and technological developments in the same period. The law was vibrant, changing as necessary to facilitate production and exchange throughout the fast growing Islamic world. Several centuries later Islamic law was still flexible in some areas, as can be seen in the quick adaptation of the Ottoman tax law to regional and temporal differences. 
Examples of openness and innovation can be found not just in its early history but more recently in modern societies, such as in adopting advancements in digital, optical, construction, and transportation technologies in the late twentieth and early twenty-first centuries. The image of economic change in the Islamic world appears to have a brighter, more flexible side.

Traditional literature has had a fundamental difficulty in explaining law and economic development in the Islamic world in its entirety, uunable to develop a framework that can bring these seemingly contradictory images into a coherent whole. Researchers have often focused on either stagnation or change as being the more representative image that needs explanation, rarely looking to explain why both images coexisted. Those considering stagnation as the more representative and problematic image have typically attributed it to a fixed characteristic of Islamic societies, such as traditionalism or religious conservatism. ${ }^{2}$ Those considering change as the more representative image, conversely, have similarly focused on such characteristics as pragmatism and flexibility for explanation, painting a more optimistic picture of the law's relationship to economic development. ${ }^{3}$ Although some writers tried to resolve the contradiction between the two images, their attempts have typically been in the form of identifying an intrinsic

${ }^{2}$ See, for example, Jones (1987, chapter 9), Landes (1969, pp. 28-30), and Lewis (1982). Studies of economic change in the modern period have also emphasized stagnation in ideas, technologies, and institutions as the ordinary state of affairs during this period. See, for example, Coulson (1964), Genç (2000), and İnalcık (1973, chapter 18).

${ }^{3}$ For example, Hassan and Hill (1990), Iqbal (2002), and İhsanoğlu (2003). 
quality of an institution or technology, such as its usefulness or religious compatibility, which has diminished over time or failed to match varying circumstances. ${ }^{4}$

Recent studies have found it useful to adopt a political economy approach to examine the relationship between law and economic change in Islamic history (Coşgel, Miceli, and Ahmed, 2009; Coşgel, Miceli, and Rubin, 2012a). This approach views the law as the outcome of the strategic interaction among rulers, general public, and organized groups powerful enough to affect the outcome. Each party is primarily interested in maximizing its own welfare, using its influence over the law to increase its share at the expense of others. Even dictatorial rulers may have a limited influence on the outcome because of their need to draw power and legitimacy from organized groups and the possibility that these groups may revolt against the ruler if their interests are sufficiently threatened. The flexibility of the law and the ability of the society to adopt new developments thus depend on the effect of these developments on their interests and on the ability of organized groups to legitimize or revolt against the ruler.

Using a political economy approach, I will focus on the relationship between the ruler and the legal-religious community to explain the nuanced flexibility of Islamic law. This community has been an influential group in Islamic societies because of its power in the interpretation and adjudication of the law and its ability to confer legitimacy on the rulers (Coşgel, Miceli, and Ahmed, 2009). The rulers have often called upon it to issue opinions on the "legality" of new developments, jointly shaping the society's decision on how to respond to new scientific, technological, and institutional developments. Studying economic change in the context of the

\footnotetext{
${ }^{4}$ Similarly, some of the recent studies of institutional change in the Islamic world have focused on the long-term trend from peak to stagnation. See, for example, Goldstone (1987), Huff (2003), and Kuran (2004).
} 
legal community's strategic interaction with the rulers and the citizenry, I will explain how change or stagnation has emerged as the outcome of this interaction, rather than from a fixed characteristic of Islamic societies or an intrinsic quality of a new development. When the ruler, legal community, and citizenry faced a new development, the loss or benefit they could expect from it depended on not just their own actions but also on the reactions of others and on their ability to manipulate these reactions. Identifying the basic factors that determined whether a society was likely to accept or reject a new development, I apply this framework to Islamic history by discussing why some of these developments resulted in change while others were ignored or rejected.

Although my focus is on the legal-religious community's role in the adoption of technology in Islamic history, the framework developed here can be extended to analyze or compare with other societies. Means of legitimization naturally varied over time and place. Organized groups could have vastly different abilities and comparative advantages across societies to legitimize the rulers, which as a result meant that a new technology could affect legitimacy differently in different societies. Whereas a new technology could diminish the ability of a dominant organized group to provide legitimacy in one society, it could have little effect on legitimizing relationships somewhere else, making the former society more likely to repress the technology. Coşgel, Miceli, and Rubin (2012b) have studied the political economy of the differential adoption of technology in such a comparative setting.

This approach is related to the recent literature on how economic or political interests could affect social outcomes. Powerful groups with vested economic interests may naturally oppose change to protect their advantages, and those in political power may similarly oppose change for fear that it may erode their incumbency advantage and political power. Focusing on the latter 
effect, Acemoğlu and Robinson (2006) have shown how political leaders, fearing replacement, have blocked economic development in history and how as a result England, Germany, Russia, and Austria-Hungary have displayed different patterns of industrialization. This chapter differs from these studies in its stress not just on the economic or political advantages of powerful groups but on their ability to legitimize the ruler. It also differs from a considerable body of literature that has explained reactions to new developments by religious and cultural factors, a view particularly common among Eurocentric approaches and in the generalist literature. ${ }^{5}$ Rather than make questionable generalizations about Muslim societies and cultures, I will rely on standard economic assumptions about the motivations of the rulers, organized groups, and the general public.

\section{The Political Economy of Change}

A society's reaction to new developments in science, technology, and institutions can be examined from a variety of perspectives. In traditional analyses of government, rulers were considered as benevolent protectors of their subjects, choosing a reaction that could best serve the interests of the general public. If other parties could influence the decision, they did so as defenders of the faith, protectors of cultural values, or representatives bound by traditions and social institutions. This type of approach emphasized the unity of values and beliefs, rather than the heterogeneity between groups or their conflicts of interests. Recent political economy models, by contrast, have viewed all parties affecting the decision as being interested in

\footnotetext{
${ }^{5}$ See, for example, Cipolla (1966), Jones (1987, chapter 9), Goldschmidt (2002, chapter 9), and Lewis (1982, chapter 9).
} 
maximizing their own welfare, often at the expense of the rest of the society (Acemoğlu and Robinson, 2006; Coşgel, Miceli, and Rubin, 2012a; Weingast and Wittman, 2006). Reactions to new developments reflected not necessarily a unified social, cultural, or religious concern but an equilibrium of the strategic interaction of interested parties.

To capture the basic legitimization relationship in a society, consider the following simplified framework of interaction between the ruler and other parties. Suppose the society consists of a ruler, an organized group whose role is to support (legitimize) the ruler, and the citizenry. The citizenry produces a surplus, part of which can be extracted by the ruler for his own consumption. The objective of the ruler is to maximize his consumption. The organized group, such as the nobility or the legal or military authority, has a choice between supporting the ruler or inciting a revolt against him. If it chooses to legitimize the ruler, the ruler can extract a surplus from the citizenry in the form of tax payments. The group's support raises the size of the surplus by making the citizenry view the ruler as legitimate and pay taxes without resistance. In return, the ruler shares his surplus with the group to elicit its support. Alternatively, rather than support the ruler, the group could choose to incite a revolt against him. If the revolt succeeds, the group obtains the surplus, but if it fails, the ruler gets the surplus and the group gets nothing. ${ }^{6}$

The ruler's desire to adopt a new idea, technology, or institution depends on how it changes the size of the surplus available to him, the ability of the group to legitimize the ruler, and the probability of a successful revolt. A development that can raise the size of the ruler's surplus, for example, would be adopted without much delay. In the same vein, the ruler would be eager to adopt a new development that can increase the ability of a group to confer legitimacy because it would increase his net revenue. But if instead a development is likely to increase the probability

\footnotetext{
${ }^{6}$ For details, see Coşgel, Miceli, and Rubin (2012a).
} 
of a successful revolt, he would oppose it. Depending on how a new development was likely to affect the ruler's surplus, his legitimacy, and the probability of revolt, we can use this framework to explain why Islamic societies accepted some developments but rejected others.

\section{The Legal Community}

The group whose relationship to the ruler will be the focus of this chapter is the legalreligious community. This community performed an essential function in mediating the ruler's relationship with the rest of the society and in formulating the society's reaction to new developments. In Islamic societies the legal community consisted of individuals trained in Islamic law serving primarily as teachers (mudarris) educating the Muslim community, as judges $(q \bar{a} d \bar{\imath})$ resolving legal disputes, or as jurisconsults (muftī) offering legal opinions. ${ }^{7}$ Members of this community performed numerous religious, social, and administrative functions, ranging from teaching the Qur'an to collecting taxes. Most important for the analysis of a society's reaction to new developments was its function of legitimizing the ruler and providing legal goods and services, including issuing rulings on the overall legality or the precise manner of application of new ideas, technologies, and institutions.

For the purpose of examining the legal community's influence on the reaction to new developments, we can treat it as monolithic - that is, as having a single, well-defined objective

\footnotetext{
${ }^{7}$ For the functions and historical evolution of the legal community, see Ghazzal (2005), Gilliot (1999), Hallaq (2005), Lambton (1981), Lapidus (1984), Masud, Messick, and Powers (1996), Zaman (2002), and Zubaida (2003). See also Toru Miura's contribution to this volume (Chapter 9) for the legal community's role in courts and contracts in a comparative perspective.
} 
function. Rather than explore divisions and coordination problems within this community, we can focus on its role in the ruler's relationship with the rest of the society. This is a reasonable simplification that can be justified by some of the well-known characteristics of the community in Islamic societies and the mechanisms that coordinated their interests against the ruler. True, there were numerous divisions within the legal community owing to differences among schools (madhhab) in Islamic law, regional variations in social characteristics and legal precedents, and differences even among those performing different types of functions in the community. The interests of these groups could conflict, creating potential for prisoners' dilemma type problems in their interaction with other organized groups. They could even disagree on what should be the role and scope of government or what constraints should be imposed on the ruler, leading to coordination problems if the ruler could exploit these differences for a divide and conquer strategy. ${ }^{8}$

The legal community did not face a significant coordination problem in influencing social outcomes. It was able to gradually establish a sense of corporate identity and develop mechanisms for commitment. As Islamic law developed, members were typically trained in schools (madrasah) that served as an entry restriction, and they were initiated through a personal relationship between student and teacher, a process that greatly fostered the sense of a corporate identity. Expectation of religiosity also helped to ensure commitment. More important from an economic perspective, the community's interaction involved mechanisms that ensured

\footnotetext{
${ }^{8}$ This is the same type of problem Weingast (2005) and Hardin (2006) have identified in the enforcement of constitutional provisions, where the government's ability to exploit disagreements among citizens can create a coordination problem and a dilemma in policing the government.
} 
cooperation and unified action. For example, members of the community interacted with each other repeatedly (rather than in one-shot situations), reputation was important, they were typically organized in a hierarchical manner, and self-selection set aside those skeptical of any interaction with the government. Although there were conflicts that occasionally troubled the community, for the most part it could be viewed as being monolithic with respect to its relationship with the ruler.

The legal community was a powerful element in Islamic societies. The source of this power could be institutional, as when a constitution might spell out its role in offering (possibly binding) opinions, or it might derive from more informal sources. Its members possessed highly specialized skills and knowledge that was difficult for the rulers or other members of the society to obtain easily. It acquired power primarily from its monopoly in interpreting the law, particularly as it pertained to the prophet's tradition. ${ }^{9}$ The demand for its services could be high and very inelastic, allowing the community to acquire tremendous power simply by controlling the provision of these services.

The power of the legal community and its ability to legitimize the ruler grew gradually over time. In the early decades of Islam, there was no organized legal community consisting of specialized legal experts. Other essential components of a complete legal system were not yet fully developed either. A positive legal doctrine was not fully elaborated, and doctrinal legal schools or a science of legal methodology and interpretation had not yet fully emerged (Hallaq, 2005). The rulers made the law and set the precedent, leaving legal interpretation and dispute resolution primarily to laymen, who served as proto- $q \bar{a} d \bar{l} s$, the earliest quasi-judges of the

\footnotetext{
${ }^{9}$ For the strength of legal community in Islamic history, see Humphreys (1991, chapter 8), Ghazzal (2005), and Zaman (2002).
} 
Islamic legal system (Hallaq, 2005, chapter 2; Crone and Hinds, 1986, chapter 4). Without an established legal system and formal training or authority, the legal community was not in a position to confer legitimacy or incite a revolt against the ruler.

The community was gradually established during the eighth and ninth centuries, a period of higher specialization in legal knowledge and greater institutionalization of the legal system. As part of a division of labor that took place between the ruler and the legal community, the legal community took over the provision of legal and religious services and acquired a monopoly in interpreting and applying the law. A key component of the transformation was the increasing importance of the tradition of Prophet Muhammad, guarded and monopolized by the legal community (Ghazzal, 2005; Hallaq, 2005). Owing to its power and expertise, the community was in a good position during this period to confer legitimacy on the rulers. As Hallaq (2005, p. 152) has observed, "the government was in dire need of legitimization, which it found in the circles of the legal profession." They could sometimes legitimize the ruler directly by serving as trustworthy and authoritative tax collectors and at other times indirectly by justifying the public benefits of the state and promoting the virtues of obedience to the ruler. Although various political conflicts erupted during this period, relatively few of them were centered on the basic question of legitimacy, as the legal community helped legitimize the ruler and reduce resistance to taxes.

By the time the Ottoman state was established in the fourteenth century, the basic ingredients of a full-fledged Islamic legal system had already been completed, and the status of the legal community was already fully established. While fully benefiting from this inherited basis for legitimacy, the Ottomans added distinct elements to their relationship with the legal community by raising its status in the eyes of the populace and bringing it under their control. They restricted 
entry to the legal community, allowed it to control the educational system, gave official status to the Hanafi School, and initiated a systematic codification and standardization of the secular law that applied to administrative matters such as taxation. They also introduced various institutional changes, such as acquiring the right to appoint the chief judges and the chief jurisconsult, which gave them the ability to manage the entire hierarchy. The legal community could confer legitimacy simply by administering justice in the courtroom, delivering sermons in mosques, and providing knowledge in schools, all as representatives of a legitimate ruler. To ensure the continuity of this support, the Ottomans had to be careful to adopt quickly those developments that could raise the community's ability to legitimize the ruler and to delay or forbid other developments that could raise the probability of a successful revolt. ${ }^{10}$

\section{Stagnation and Change in Islamic History}

Using the framework developed above, we can now analyze the reactions to new ideas, technologies, and institutions in Islamic history. Three general cases were possible. The ruler could be eager to adopt a new development as quickly as possible; he could be indifferent toward its adoption; or he could oppose it strongly and ban or delay its adoption. Focusing on the role of the legal community, we analyze each possibility in detail, identify the reasons that caused the reaction, and use examples for illustration.

Eagerness to Adopt New Ideas, Technologies, Institutions

\footnotetext{
${ }^{10}$ For recent studies of the Ottoman legal system, see Gerber (1994), Imber (2002, chapter 6), Vikør (2005), and Zilfi (1988).
} 
he rulers were sometimes eager to adopt a new development quickly. Recall from the discussion above that this could be the case if they expected a new idea, technology, or institution to raise the size of the surplus available to them, increase the legal community's ability to legitimize the ruler, and lower the probability of a successful revolt. If they expected the benefits to be large in one of these respects, they could adopt a new development eagerly so long as there was no significant cost associated with it in other respects.

Eagerness was the typical attitude toward new developments in military technology. Gunpowder weapons, for example, were quickly adopted in the Islamic world, as can be seen from recent research on the Ottomans (Ágoston, 2005). Realizing the advantages of gunpowder weapons, they integrated them into their army as swiftly as possible. They not only kept pace with developments in gunpowder, firearms, and cannons but displayed ingenious organizational skills by pioneering the establishment of a permanent standing army (the Janissaries) specialized in the use of these weapons well before the European powers. They showed such remarkable success in assimilating gunpowder technology in their army and navy that by the mid-fifteenth century they achieved a clear logistical and firepower superiority over their European and Asian adversaries.

The Ottomans were generally eager to accept a new military technology because they expected it to raise the revenue available to them without significant adverse consequences to their basis for legitimacy or the probability of a successful revolt against their rule. A new military technology could raise the size of the surplus available to the Ottomans by expanding their revenue base through conquests and tributes or helping them protect existing revenues from being confiscated by adversaries equipped with the new technology. Advances in military technology had little effect on the legitimization relationship between the ruler and the legal 
community, and their adoption faced no objections from the legal community. Although new weapons could raise the ability of military authorities to legitimize the ruler, the legal community used a different type of mechanism, namely, oral indoctrination rather than military force to confer legitimacy, which was unlikely to be affected by changes in military technology. ${ }^{11}$ These changes had a similarly negligible effect on the probability of a successful revolt because of various measures the Ottomans took to maintain their monopoly in organized violence. They controlled rural banditry by striking bargains with their leaders and incorporated bandits into the system by recruiting them as irregular soldiers (Barkey, 1994). They also implemented a system of periodic rotation of offices through which government officials were rotated on a more or less regular schedule and were prevented from forming potential alliances with rebellious movements (Barkey, 1996). Because advances in military technology could raise the size of the surplus available to them without having a significant effect on the legitimization relationship between the rulers and the legal community or on the probability of revolt, the rulers accepted them eagerly.

The Ottomans were also quick to adopt new methods of taxation and tax collection. Upon conquering a new region, they readily adopted some of the basic elements of the prevailing tax customs, rather than impose a rigid system throughout the empire (Coşgel, 2005). The result was an extremely flexible tax system, the code varying greatly between regions. The names and rate structures of personal taxes, for example, varied significantly. Under the conventional system observed in Asia Minor, personal taxes were based on adult males, and the tax rate varied by

\footnotetext{
${ }^{11}$ See Coşgel, Miceli, and Rubin (2012a) for the effect of new military technology on the ability of military authorities to confer legitimacy. This effect is omitted here to maintain our focus on the legal community.
} 
marital status and land ownership. The subjects in Hungary, in contrast, paid personal taxes as a gate $(\mathrm{kap} \iota)$ tax, for which the unit of taxation was the household, rather than adult males, and the tax amount did not change according to marital status or land ownership. Moreover, personal taxes were not even fully implemented in all areas (though non-Muslim subjects throughout the empire paid a poll tax called cizye). In Jerusalem and surrounding districts, the Ottomans did not introduce the çift tax or any other form of personal tax systematically levied on individuals or households. The system was also flexible to change over time, as can be seen in methods of tax collection. Whereas early in the empire's history the government relied on salaried commissioners and on cavalrymen (sipāhiss) who received tax grants in exchange for military service, the importance of tax farming grew during the sixteenth and seventeenth centuries, consistent with parallel developments observed in Europe and other parts of the world (Coşgel and Miceli, 2009).

The legal community played a significant role in adopting these changes as part of its responsibility to draft the tax code of the empire and perform its function of legitimizing the ruler. Soon after the conquest of a new region, members of the legal community went to work in drafting its code, basing it on the basic structure of Ottoman taxation and the prevailing local rules and policies (Coşgel, 2004). They revised the code over time as circumstances changed.

The Ottoman rulers were eager to adopt changes to the tax code and methods of tax collection, because a flexible tax code could raise the size of the surplus available to them, advance the ability of the legal community to confer legitimacy, and reduce the probability of a successful revolt. If the tax burden was high in a newly conquered area, the Ottomans were better off maintaining high revenues by adopting the prevailing tax system than changing it, as long as the system was efficient. But in some areas they inherited inefficient tax systems, such as the 
labor dues in the Balkans, which they quickly converted to cash payments to eliminate adverse consequences for agricultural production. The other beneficial effect of a flexible tax code was to raise the ability of the legal community to legitimize the ruler. As argued, their power and income emanated from their monopoly on interpreting the law, which was likely to grow stronger under a flexible tax system that allowed them to discriminate the rates among regions. By maintaining a flexible code that minimized resistance and ensured implementation, they legitimized the ruler and lowered the cost of tax collection. While raising the ruler's surplus or legitimacy, these changes could also reduce the probability of a successful revolt. Labor dues were not only inefficient but also despised by the peasants, and eliminating them reduced the likelihood of rebellion against Ottoman rule. Alternatively, it was sometimes safer to preserve those taxes that were familiar and acceptable to the local population than to impose a rigid structure from the center. Adapting to local and temporal conditions quickly allowed the Ottoman tax system to benefit the ruler in revenue, legitimacy, and minimizing the likelihood of revolt.

More recently, some rulers have shown similar eagerness toward the institutional innovations proposed by the modern movement called Islamic economics. Muslim rulers, particularly in societies where religion has continued to exert a strong influence on the law, have been quick to adopt some of the new interpretations of Islamic law, such as innovative interpretations of the ban on interest that facilitated capital markets through "Islamic banking." They have also been eagerly involved in the administration of $z a k \bar{a} t$, one of the five pillars of Islam, by promoting the religious principle as a civilian obligation, accepting its interpretation as a public tax rather than a private payment, and even expanding the obligation to corporations. 
The rulers adopted some of the elements of Islamic economics eagerly because these elements raised their revenue, improved legitimacy, and reduced the probability of revolt. Their revenue rose because Islamic banking increased taxable activity, and state involvement in zakāt collection raised tax revenues. The religious basis for these ideas also advanced the power of the legal community and its ability to legitimize the ruler. To the extent that these developments helped alleviate dissent and poverty without changing the total tax burden, they lowered the likelihood of a successful revolt.

Muslim societies have also been eager to adopt or lead some of the technological and institutional advances in recent history. In addition to adopting most of the advances in digital, optical, and transportation technologies in the late twentieth and early twenty-first centuries, they founded modern public and private educational institutions and led the world in introducing some of the novel economic institutions and organizational innovations, such as the Organization of Petroleum Exporting Countries in the Middle East and microfinance in Bangladesh, overseeing one of the largest urban development projects in the world in recent history in Dubai. Many of these advances have been accepted eagerly because of their parallel implications for the surplus available to rulers, legitimacy, and reducing the likelihood of revolt.

\section{The Ruler's Indifference Toward New Developments}

The rulers were sometimes indifferent to a new scientific, technological, or institutional development because it did not affect them significantly. Two scenarios could lead to the net effect of a development on the ruler being negligible. First, the cost or benefit of a development on the ruler's surplus, his legitimacy, or the probability of revolt might be too small to catch his attention or to provoke great enthusiasm or opposition. The introduction of various consumption 
goods invented elsewhere, such as eyeglasses and clocks, was often greeted with indifference, and consequently they were adopted by default. Similarly, although Muslim rulers suppressed the printing press in the fifteenth century, they were previously indifferent to the adoption of paper, a Chinese invention. Muslim scholars and scientists appropriated the bulk of Greek science and philosophy during the eighth and ninth centuries and ultimately achieved great accomplishments in such disciplines as medicine, optics, astronomy, and mathematics, all without opposition from the rulers. ${ }^{12}$ Although these were great scholarly and scientific accomplishments, the cost and benefit to the ruler's surplus, his legitimacy, and probability of revolt was often negligible, and there was no major reason for them to occupy the ruler's attention extensively. The ruler typically did not show great enthusiasm (regarding their effect on his concerns) toward this type of development; nor did he oppose them vehemently.

Another scenario leading to indifference was when a new development could provide substantial benefits to one of the ruler's concerns (surplus, legitimacy, or revolt) but was also accompanied by a similarly substantial cost to another concern. If, for example, a new technology was expected to raise the ruler's surplus significantly but only at the cost of raising the likelihood of revolt by a comparable magnitude, the rulers would react to this technology with indifference. Despite expecting substantial benefits, they would be in no rush to adopt it quickly; nor would they have a great need to reject or delay its adoption, because the net effect would be negligible. Other concerns would determine the outcome.

A development that was adopted despite its high cost was the Islamic institution of charitable foundations known as the waqf (Kuran, 2001). Under a system of private provision of public

\footnotetext{
${ }^{12}$ See also Goldstone (1987, p. 130), Hassan and Hill (1990), Hogendijk and Sabro (2003), Iqbal (2002), and Mokyr and American Council of Learned Societies (1990, pp. 34-35).
} 
goods, waqfs produced many of the public and semipublic goods and services demanded by the earlier Islamic societies before this responsibility was taken over by modern governments. They supported mosques, schools, hospitals, and numerous other social services, each established as an unincorporated trust under Islamic law and financed by the earnings of an immovable property turned into an endowment. Endowing a property as waqf made it exempt from taxation and gave it substantial immunity from expropriation. The legal basis for this system was incorporated into Islamic law around the middle of the eighth century, and it was eventually adopted by all successive Islamic societies.

Although the rulers stood to lose tax revenues from the endowment of property as waqfs, they adopted the system because it raised the ability of the legal community to confer legitimacy and lowered the likelihood of a successful revolt. Waqfs provided much of the financial support for the legal community. By funding the education and remuneration of its members and maintaining the institutions and infrastructure of its activities, they raised the community's stature and its ability to confer legitimacy. They also lowered the likelihood of revolt against the ruler by offering numerous services that enhanced material security, raised the citizen's welfare, and reduced popular discontent. Many services, such as those offered by orphanages, shelters, and soup kitchens, were directed toward the poor and the disadvantaged, meeting their basic needs and eliminating their motivation to initiate or participate in a revolt. Despite suffering a substantial loss from the waqf system in tax revenue, the rulers adopted it because the benefits were also substantial. $^{13}$

\footnotetext{
${ }^{13}$ For detailed analyses of the waqf system, see Gibb and Bowen (1957, vol. 1, part 2, chapters 10 and 12), Huff (2003, chapters 4 and 6), Kuran (2001), and Schacht (1970).
} 


\section{Strong Opposition to New Developments}

While some developments were eagerly accepted and others faced lukewarm reception, still others were rejected outright. The preceding discussion has shown that just because a new development was likely to reduce the surplus available to the ruler did not mean it would be rejected. Despite causing a significant loss in surplus, it could still be adopted if the loss was offset by benefits in legitimacy and/or the likelihood of revolt. But if the ruler suffered a loss not just in surplus but also in legitimacy and likelihood of revolt, or if the loss in one of these areas was substantially greater than benefits in others, he could reject a new development immediately. Some of the new developments in science, technology, and institutions were rejected or delayed significantly because the net loss would have been too large.

A good example of this was the immediate opposition and significant delay in the adoption of the printing press. Within decades after the appearance of Gutenberg's first book published by moveable type in Germany, the Ottoman sultan is said to have issued an edict that banned printing in Arabic characters (which was used to write Turkish as well) in 1485 (Savage-Smith, 2003, p. 656). Despite clear awareness of the new printing technology and successful reproduction of it within Ottoman lands by religious minorities, the process of accepting the printing press was extremely slow. Even after the rulers started to relax the ban in 1726, they continued to regulate the operation closely by granting permission only to selected individuals, prohibiting publication on religious subjects, and appointing a committee of scholars to review and proofread contents for accuracy. ${ }^{14}$ It was not until well into the nineteenth century that rulers became eager, and there was widespread use of mass printing technologies. The lithographic

\footnotetext{
${ }^{14}$ See Atiyeh (1995, pp. 284-285) for an English translation of the 1726 royal order.
} 
press was adopted within a few decades after its invention, and a press was established to print an official newspaper (Kut, 1991, p. 802).

The rulers were unenthusiastic about the printing press from its invention until the nineteenth century because they expected it might undermine the ability of religious authorities to confer legitimacy and might increase the likelihood of a successful revolt against their reign, even though it could raise the size of the surplus available to them. Judging solely by its effect on economic activities (indirectly on tax revenues) in Europe, perhaps Muslim rulers would have been better off adopting the printing press immediately. But the effect would have been less in the Islamic world than in Europe. Just because the printing press had revolutionized intellectual and economic developments in early modern Europe (Eisenstein, 1979; Baten and van Zanden, 2008) did not mean it would have had the same influence in the Ottoman Empire because wages and literacy rates were significantly lower in the Ottoman Empire than in Western Europe (Özmucur and Pamuk, 2002; Quataert, 2000, p. 167). Moreover, if adopted, the printing press would have undermined the ability of religious authorities to confer legitimacy. In early modern Muslim societies, the legal-religious authorities had a monopoly on providing legitimacy through indoctrination because the transmission of knowledge depended on oral technology, and the authorities had a vast comparative advantage in this type of transmission. ${ }^{15}$ The introduction of the printing press would have altered this ability by changing the technology of transmitting knowledge and diminishing the comparative advantage of religious authorities. The general public could obtain knowledge directly from books or from literate individuals not necessarily affiliated with religious authorities. In addition, the rulers feared mass printing because it may

\footnotetext{
${ }^{15}$ For the importance of the oral tradition in Muslim courts, see Lydon (2009) and Chapter 9 in this volume.
} 
have promoted successful revolt. Mass printing could be a very effective weapon in inciting rebellion, as was the case in the American Revolution and the Protestant Reformation. ${ }^{16}$ Although the printing press could have raised the surplus available to the rulers by a margin, Muslim rulers still chose to ban it because it would have jeopardized their legitimacy and increased the likelihood of a successful revolt.

The same can be said about the significant delay in the adoption of the legal concept of the corporation. Although some Western legal systems recognized the concept as early as the twelfth century, the Islamic world waited until the twentieth century, relying instead on persons and small partnerships as the dominant form of organization (Kuran, 2005). Perhaps the rulers should have rushed to adopt the corporate form of business because it could have raised the surplus available to them by facilitating greater capital accumulation and greater production and incomes. Muslim rulers were familiar with the general concept of a corporation, as they selectively recognized ad hoc corporate public bodies such as guilds and tax farmers because they promoted more efficient tax collection. But they did not extend the same recognition to the corporate form of business organization.

Although the corporation could have increased the size of the surplus available to rulers, they did not adopt it because of its possible effects on legitimacy and revolt. The corporation could have jeopardized the ruler's legitimacy by opening the door to the rise of groups rivaling the legal community that would be outside of his control. Members of the legal community retained a monopoly on the interpretation of legal and religious texts as individuals with legal training.

\footnotetext{
${ }^{16}$ Mass printing could be effective even in societies with low levels of literacy, as was seen in the use of broadsides and caricatures by Protestants in antipapist propaganda in the sixteenth century (Eisenstein, 1979, p. 304).
} 
Their monopoly could be threatened if recognition of the abstract concept of a corporation led to the rise of incorporated offices or organizations with significant powers. The corporation could also raise the likelihood of a successful revolt if it allowed rebellious classes of individuals to organize under corporate autonomy and gather financial support for their activities. Even though the rulers could have benefited from the corporation's effect on economic welfare, they did not recognize the concept because it could have undermined the ability of the legal community to confer legitimacy and increased the risk of revolt.

Muslim rulers have opposed numerous other developments with similar implications for surplus, legitimacy, and revolt. Some well-known examples for this are democratic institutions, new theories of the universe that challenged the status of rulers or the legal community, new technologies that made it easier for fringe groups to organize, and legal developments that gave women greater rights in patrimonial empires with male-dominated legal communities. Labeling such developments as "Western" or "foreign," the rulers and legal communities have opposed them, not necessarily because of religious or cultural concerns but because of threats to their interests.

\section{Conclusion}

Islamic societies have shown a mixed reaction to new developments in science, technology, and institutions. While some of these developments have been adopted swiftly, others have been rejected outright or delayed significantly. To provide a comprehensive explanation of these outcomes, I have adopted a political economy approach and focused on the legal community's 
relationship with the ruler and the citizenry. ${ }^{17}$ When the rulers expected new developments to raise the revenue available to them while having a positive effect on legitimacy or revolt, they adopted them eagerly. When the adoption of a new development would have cost the ruler greatly in surplus, legitimacy, and likelihood of revolt, however, they rejected it if the cost was too high to be offset by benefits. Muslim rulers thus banned the printing press and delayed the adoption of the legal concept of the corporation, because these developments could undermine the ability of religious authorities to confer legitimacy and increase the likelihood of a successful revolt.

The static framework of the political economy approach adopted here helps to explain the variety of reactions observed in the Islamic world, but it also raises questions about how these reactions varied over time and in other parts of the world. Why was a new development that was suppressed in one part of the Islamic world easily accepted in others, and why were some of the initially suppressed developments eventually adopted? For example, while the Ottomans banned the printing press in the fifteenth century, most European states allowed it without much delay; and although the Ottomans continued the ban for a long time, they eventually did allow it. To explain these variations, we need to expand our view to incorporate other agents (such as the military or the nobility) who could also legitimize rulers. Adopting a more dynamic framework, we can then identify how broader macroeconomic and institutional factors determined substitutability among these agents and how rulers reacted differently to new developments over time and across societies as a result of variations in substitutability. ${ }^{18}$

\footnotetext{
${ }^{17}$ For the roles of other organized groups, such as the nobility or the military, see Coşgel, Miceli, and Rubin (2012b).

${ }^{18}$ For attempt in this direction, see Coşgel, Miceli, and Rubin (2012a, 2012b).
} 


\section{References}

Acemoğlu, Daron, and James A. Robinson. 2006. "Economic Backwardness in Political Perspective," American Political Science Review 100 (1): 115-131.

Ágoston, Gábor. 2005. Guns for the Sultan: Military Power and the Weapons Industry in the Ottoman Empire. Cambridge Studies in Islamic Civilisation. Cambridge: Cambridge University Press.

Atiyeh, George N. 1995. The Book in the Islamic world: The Written Word and Communication in the Middle East. Albany: State University of New York.

Barkey, Karen. 1994. Bandits and Bureaucrats: The Ottoman Route to State Centralization. The Wilder House Series in Politics, History, and Culture. Ithaca, NY: Cornell University Press.

—. 1996. "In Different Times: Scheduling and Social Control in the Ottoman Empire, 1550 to 1650," Comparative Studies in Society \& History 38 (3): 460.

Baten, Joerg, and Jan Luiten van Zanden. 2008. "Book Production and the Onset of Modern Economic Growth,” Journal of Economic Growth 13 (3): 217-235.

Cipolla, Carlo M. 1966. Guns, Sails and Empires; Technological Innovation and the Early Phases of European Expansion, 1400-1700. Pantheon Studies in Social History. [Guns and Sails in the Early Phase of European Expansion, 1400-1700]. 1st American ed. New York: Pantheon Books. 
Coşgel, Metin M. 2004. “Ottoman Tax Registers” (tahrir defterleri), Historical Methods 37 (2): $87-100$.

—. 2005. "Efficiency and Continuity in Public Finance: The Ottoman System of Taxation,” International Journal of Middle East Studies 37 (4): 567-586.

Coşgel, Metin M., Thomas Miceli, and Rasha Ahmed. 2009. “Law, State Power, and Taxation in Islamic History," Journal of Economic Behavior and Organization 71 (3): 704-717.

Coşgel, Metin M., Thomas J. Miceli, and Jared Rubin. 2012a. "The Political Economy of Mass Printing: Legitimacy, Revolt and Technological Change in the Ottoman Empire,’ Journal of Comparative Economics, 40: 357-71.

—. 2012b. "Political Legitimacy and Technology Adoption," Journal of Institutional and Theoretical Economics 168(3): 339-361.

Coulson, Noel J. 1964. A History of Islamic Law. Islamic surveys. Vol. 2. Edinburgh: University Press.

Crone, Patricia, and Martin Hinds. 1986. God's Caliph: Religious Authority in the First Centuries of Islam. University of Cambridge Oriental Publications. Vol. 37. Cambridge: Cambridge University Press.

Eisenstein, Elizabeth L. 1979. The Printing Press as an Agent of Change: Communications and Cultural Transformations in Early Modern Europe. Cambridge: Cambridge University Press.

Genç, Mehmet. 2000. Osmanlı imparatorluğunda devlet ve ekonomi. Kültür serisi. İstanbul: Otüken. 
Gerber, Haim. 1994. State, Society, and Law in Islam: Ottoman Law in Comparative Perspective. Albany: State University of New York Press.

Ghazzal, Zouhair. 2005. "The 'Ulama': Status and Function," in A Companion to the History of the Middle East., ed. Youssef M. Choueiri, 71-86. Malden, MA: Blackwell.

Gibb, H. A. R., and Harold Bowen. 1957. Islamic Society and the West; a Study of the Impact of Western Civilization on Moslem Culture in the Near East. London: Oxford University Press.

Gilliot, Claude. 1999. "'Ulamā," in The Encyclopaedia of Islam. New ed., vol. 10, 801805. Leiden: Brill.

Goldschmidt, Arthur. 2002. A Concise History of the Middle East. 7th ed. Boulder, CO: Westview Press.

Goldstone, Jack A. 1987. "Cultural Orthodoxy, Risk, and Innovation: The Divergence of East and West in the Early Modern World," Sociological Theory 5 (2): 119-135.

Hallaq, Wael B. 2005. "The Origins and Evolution of Islamic Law," Themes in Islamic Law. Vol. 1. Cambridge: Cambridge University Press.

Hardin, Russell. 2006. "Constitutionalism," in The Oxford Handbook of Political Economy, ed. Barry R. Weingast, Donald A. Wittman, 289-311. Oxford: Oxford University Press.

Ḥasan, Aḥmad Yūsuf, and Donald Routledge Hill. 1992. Islamic Technology: An Illustrated History. 1st paperback ed. Cambridge: Cambridge University Press. 
Hogendijk, J. P., and A. I. Sabra. 2003. The Enterprise of Science in Islam: New Perspectives. Dibner Institute for the History of Science and Technology. Cambridge, MA: MIT Press.

Huff, Toby E. 2003. The Rise of Early Modern Science: Islam, China, and the West. 2nd ed. Cambridge: Cambridge University Press.

Humphreys, R. Stephen. 1991. Islamic History: A Framework for Inquiry. Rev. ed. London: I. B. Tauris.

Insanoglu, Ekmeleddin. 2003. Science, Technology, and Learning in the Ottoman Empire: Western Influence, Local Institutions, and the Transfer of Knowledge. Variorum collected studies series. Vol. 773. Burlington, VT: Ashgate.

Imber, Colin. 2002. The Ottoman Empire, 1300-1650: The Structure of Power. New York: Palgrave.

İnalc1k, Halil. 1973. The Ottoman Empire: The Classical Age, 1300-1600. History of Civilization. London: Weidenfeld and Nicolson.

Iqbal, Muzaffar. 2002. Islam and Science. Ashgate Science and Religion Series. Aldershot, UK: Ashgate.

Jones, E. L. 1987. The European Miracle: Environments, Economies, and Geopolitics in the History of Europe and Asia. 2nd ed. Cambridge: Cambridge University Press.

Kuran, Timur. 2001. "The Provision of Public Goods Under Islamic Law: Origins, Impact, and Limitations of the waqf system," Law \& Society Review 35 (4): 841-897. 
—. 2004. "Why the Middle East Is Economically Underdeveloped: Historical Mechanisms of Institutional Stagnation," Journal of Economic Perspectives 18 (3) (Summer): 71-90.

_. 2005. "The Absence of the Corporation in Islamic Law: Origins and Persistence," American Journal of Comparative Law 53: 785-834.

Kut, Günay Alpay. 1991. "Matba'a. 2. in Turkey,” in The Encyclopaedia of Islam. New ed., vol. 6, 799-803. Leiden: Brill.

Lambton, Ann K. S. 1981. State and Government in Medieval Islam: An Introduction to the Study of Islamic Political Theory: The Jurists. London Oriental series. Vol. 36. Oxford: Oxford University Press.

Landes, David S. 1969. The Unbound Prometheus. Cambridge: Cambridge University Press.

Lapidus, Ira M. 1984. Muslim Cities in the Later Middle Ages. Student ed. Cambridge: Cambridge University Press.

Lewis, Bernard. 1982. The Muslim Discovery of Europe. 1st ed. New York: W. W. Norton.

Lydon, Ghislaine. 2009. “A Paper Economy of Faith Without Faith in Paper: A Reflection on Islamic Institutional History," Journal of Economic Behavior and Organization 71 (3): 647659. 
Masud, Muhammad Khalid, Brinkley Morris Messick, and David Stephan Powers. 1996. Islamic Legal Interpretation: Muftis and Their Fatwas. Harvard Studies in Islamic Law. Cambridge, MA: Harvard University Press.

Mokyr, Joel, and American Council of Learned Societies. 1990. The Lever of Riches. New York: Oxford University Press.

Nasr, Seyyed Hossein. 1995. "Oral Transmission and the Book in Islamic Education," in The Book in the Islamic World: The Written Word and Communication in the Middle East., ed. George N. Atiyeh, 57-70. Albany: State University of New York Press.

Özmucur, Süleyman, and Sevket Pamuk. 2002. "Real Wages and Standards of Living in the Ottoman Empire, 1489-1914," Journal of Economic History 62 (2): 293-321.

Quataert, Donald. 2000. The Ottoman Empire, 1700-1922. Cambridge: Cambridge University Press.

Savage-Smith, Emilie. 2003. "Islam," in The Cambridge History of Science, vol. 4: Eighteenth-Century Science., ed. Roy Porter. Cambridge: Cambridge University Press.

Schacht, Joseph. 1970. "Law and Justice," in The Cambridge History of Islam., ed. P. M. Holt, Ann K. S. Lambton, and Bernard Lewis. Cambridge: Cambridge University Press.

Vikør, Knut S. 2005. Between God and the Sultan: A History of Islamic Law. Oxford: Oxford University Press.

Weingast, Barry R. 2005. “The Constitutional Dilemma of Economic Liberty,” Journal of Economic Perspectives 19 (3) (Summer): 89-108. 
Weingast, Barry R., and Donald A. Wittman. 2006. The Oxford Handbook of Political Economy. The Oxford Handbooks of Political Science. Oxford: Oxford University Press.

Zaman, Muhammad Qasim. 2002. The Ulama in Contemporary Islam: Custodians of Change. Princeton Studies in Muslim Politics. Princeton, NJ: Princeton University Press.

Zilfi, Madeline C. 1988. The Politics of Piety: The Ottoman Ulema in the Postclassical Age (1600-1800). Studies in Middle Eastern History. Vol. 8. Minneapolis: Bibliotheca Islamica.

Zubaida, Sami. 2003. Law and Power in the Islamic World. Library of Modern Middle East Studies. London: I. B. Tauris. 